\title{
An Investigation of Employment Choice in the Rural Sector of Pakistan
}

\author{
Faisal Jamil $^{1}$ and Saeeda Batool ${ }^{2}$
}

\begin{abstract}
Agricultural sector remained the focus of policy makers in an attempt to improve the rural incomes and reducing rural poverty among highly populated but less developed countries. The paper analyzes the workers' choice between farm and nonfarm sectors in the rural sector. The study provides a theoretical framework where the employment decision of rural household member in the farm and nonfarm sectors depends on its physical assets including landholding and human capital development. The empirical analysis uses data for Pakistan obtained from PIHS 2001-02 and PSLM 2010-11. The results of the empirical model show that landholding is the major factor that drives the individual towards the farm activity while, education and public policy incentives including connectivity, market access and information spur the nonfarm employment. The findings of the study favor the development of nonfarm sector in order to cope with excessively increasing number of rural semi-skilled young workers. The findings suggest that focus of the policy should be on education and training to provide an enabling environment for sustained earnings of individuals. Nonfarm sector employment may ensure sustainable income of the rural labor as well as production of exportable surplus from rural to urban areas. This is inevitable due to poor economic conditions of rural workers and limited absorption capacity of farm and the urban job markets in the country.
\end{abstract}

Keywords: Diversification, Rural Households, Landholding, Nonfarm Sector, Pakistan JEL Classification: C51, D13, Q12

\section{Introduction}

Rural poverty is a matter of prime policy concern in Pakistan. Income and employment choices of rural workers are linked with many cross-cutting socioeconomic issues like poverty reduction, climate change and gender equality. Rural households derive their incomes either from farm or nonfarm sector. Assuming that farm activity is obviously the first employment choice in the rural areas therefore, most of the government policy interventions essentially focus on

\footnotetext{
${ }^{1}$ Associate Professor, School of Social Sciences \& Humanities, National University of Science \& Technology, Islamabad.

${ }^{2}$ Assistant Professor, School of Social Sciences \& Humanities, National University of Science \& Technology, Islamabad.

Corresponding author's Email: Faisal.jamil@s3h.nust.edu.pk
} 
achieving the growth of farm output. Further, literature on development economics asserts that policy measures should focus on stimulating and facilitating sustainable employment in rural settings through channelizing resources to enhance the opportunities for vulnerable groups such as women, the landless and the marginalized poor.

Literature and evidence suggest that rural development strategies generally focus on agricultural intensification for ensuring livelihood and employment, and reducing poverty (Wiggins, 2000; Diao et al., 2010). Empirical findings suggest that implementing policies that enhance farm productivity primarily among smallholders would prove to be pro-poor (Start, 2001; Birner and Resnick, 2010). The Green Revolution was a thorough drive towards this direction in Pakistan that has increased agricultural productivity by improving crop intensity and investment in the farm sector. This development path paid off significantly but agricultural growth rate ceased to rise after 1980s. Decreasing farm sizes and reduced productivity gaps are the major reasons of rather stationary growth in the farm incomes. Mechanization reduces the capacity of family farms to absorb increasing number of rural workers. The features of climatic risks, information asymmetry and thin credit and insurance markets in the country signify the role of nonfarm sector to augment family income. In this backdrop, the rural households consider nonfarm employment as a coping up strategy for risk reduction and stabilizing income. Therefore, an identification of factors that spur the rural nonfarm sector is a worthwhile analytical activity that should be considered imperative in designing an appropriate policy intervention.

Past studies identify various factors that raise employment in nonfarm sector such as physical infrastructure, $R \& D$ and human capital development. Literature shows that rural households allocate their labor and physical resources in response to socioeconomic changes that crucially depend on allocative abilities and capital holding of household members. Many contemporary studies suggest that inability of rural households to shift surplus labor from the farm to nonfarm sector adds to rural poverty as the workers are generally characterized having poor skills set that make them unsuitable for employment elsewhere in the commercial and industrial sectors. Literature identifies a phenomenal role of human capital formation in driving individuals to superior employment options in the nonfarm sector (Yunez-Naude and Taylor, 2001; De Janvry and Sadoulet, 2001). Malik (1996) examines the determinants of poverty in rural areas of Pakistan and finds that the possibility of being poor lessens for households who cultivate a larger land, have access to other productive assets, participate in nonfarm activities and more importantly, attained a higher level of education. Several past studies investigated 
decision of employment and income generating strategies of rural workers by employing microeconomic modelling where households purchase intermediate goods from inputs market and combine them with time in a "household production function" to produce consumable goods. Since purchased goods and time serve as inputs into the production of intermediate goods hence, the consumable goods rather than the purchased inputs are the arguments of utility function in these studies (De Haan and Zoomers, 2005).

Economic theory suggests that labor in rural sector would be allocated among the farm and nonfarm employment such that marginal value of farm output equals earnings in nonfarm labor market. Mechanization reduces the opportunity cost of shift in labor from farm to nonfarm sector. Furthermore, some of the farm workers may be released for other activities due to their increased education levels and changing roles of family members. Rural household members allocate their labor hours between farm and nonfarm sectors in order to reduce income risk by diversifying employment either to maintain cash earnings and/or to finance farm investments. Rural economy increasingly interacts with external labor markets and there exists a positive correlation between farm income and nonfarm employment as well as education and employment in the nonfarm sector (Mishra and Goodwin, 1997; Berdegué et al., 2001; Chang et al., 2017).

This paper investigates how an individual in the rural household chooses among alternative employment options and identifies the determinants of employment choice in rural areas of Pakistan. It develops a theoretical model of individuals' work choice in order to find appropriate policy interventions and institutional arrangements that may be required for sustainable income. The paper assumes that farm activities are dominant and default first choice in the rural areas of Pakistan and it further assesses importance of nonfarm sector as an alternative employment option adopted by rural workers and operationally examines the employment trends therein. The empirical analyses identify the factors that help individuals in choosing between farm or nonfarm employment. The study compares two datasets covering a decade period. The study utilizes data from Pakistan Social and Living Standards Measurement Survey (PSLM) 2010-11, and the Pakistan Integrated Household Survey (PIHS) 2001-02.

The employment choice of an individual in the farm and nonfarm sector is found to depend on his endowment set wherein the farm size and livestock holding lead the individual to choose farm activities while, education and market access encourages nonfarm employment. Development strategies postulate that the asset holdings of the poor can generally be improved either by endowing them with 
additional financial, human or social assets or through increasing the productivity of those assets.

The rest of the paper is as follows. Section 2 illustrates a description of the rural economy in Pakistan. Section 3 presents the theoretical framework. We proceed by presenting the model in Section 4 and estimation results for the two time periods are presented in Section 5. Finally, Section 6concludes the findings and discuss some policy implications.

\section{Rural Sector and Employment Strategies}

Rural economy is extremely important in Pakistan as almost $2 / 3^{\text {rd }}$ of its population lives in rural areas. The share of agriculture has been the highest in providing employment and income to the rural population. Agriculture is the basic occupation in the rural areas and accounts for $19 \%$ of GDP and an overall share of $38.5 \%$ in employment (Pakistan Economic Survey, 2017-18). Historically, land ownership is considered a source of family prestige in the rural setup and cultural factors may make some casts and families landless de facto. Therefore, this social inhibition left them with nonfarm option only. The cottage industries and professions in the nonfarm sector contribute significantly in the rural incomes. Formally qualified teachers, doctors, para-medical staff and domestically trained rural workers such as, carpenters, blacksmiths, potters, craftsmen and cotton weavers has been producing for the rural consumers and supporting the farm economy since long while in recent times they also sell their output in the urban commodity markets. Many individuals choose self-employment by running grocery store or become brokers dealing in agricultural commodities. Occupational diversification among the household members is a strategy that enables them to reduce risk by allocating human capital and time of its members among various activities and industries that would each react differently to different events that may affect the household earnings. A household member may detach from farm sector and take on nonfarm work either a paid job or self-employment. Many of such rural households have either no land at all or relatively high landholding. Anwar et al. (2004) find that rural poverty in Pakistan is strongly linked with landlessness and can be mitigated by livestock holdings of households. Table 1 shows the shrinking farm sizes in Pakistan over time.

In this scenario, many of the rural households lack economic resources such as physical capital and human capital (in the form of education and training) that may assist them in improving their productivity and earnings. The nonfarm sector provides income and livelihood to resource poor households as a coping strategy that help them to cover up the lack of land and financial resources as well as it also 
offers higher income prospects by giving choice and opportunity to all rural workers. The structure of work schedules in the farm activities may support individuals to create complementarity between the farm and nonfarm work. The Agriculture Census of Pakistan shows that rural population get a significant share of their incomes from nonfarm sources (Batool and Jamil, 2019). Rigg (2006) identifies five common changes taking place in the rural sector that favor nonfarm employment including, the dissipation of profitability and returns to smallholder from agricultural production: opportunities in the nonfarm sector, environmental degradation, increasing land and water shortages and cultural and social change. More specifically, the occupational transition out of agriculture to the nonfarm sector may take place as some individuals shift from farm to nonfarm employment due to higher expected earnings or new entrants in labor force choose the nonfarm sector while their parents remain in the farming sector at the same time. Moreover, mechanization increases the productivity of a farm worker and resultantly, some of the farm labor become under-employed or unemployed. Some rural workers may also hold dual jobs and choose nonfarm work along with the farm work.

Table 1: Trend of Declining Farm size in Pakistan (1990-2010)

\begin{tabular}{|c|c|c|c|c|c|c|}
\hline \multirow{2}{*}{$\begin{array}{c}\text { Farm } \\
\text { Size (Ha) }\end{array}$} & \multicolumn{2}{|c|}{1990} & \multicolumn{2}{|c|}{2000} & \multicolumn{2}{|c|}{2010} \\
\hline & $\begin{array}{c}\text { Number } \\
\text { in thousand }\end{array}$ & $\begin{array}{c}\text { Area } \\
(000, \text { Ha })\end{array}$ & $\begin{array}{c}\text { Number } \\
\text { in thousand }\end{array}$ & $\begin{array}{c}\text { Area } \\
(000, \mathbf{H a})\end{array}$ & $\begin{array}{c}\text { Number } \\
\text { in thousand }\end{array}$ & $\begin{array}{c}\text { Area } \\
(000, \text { Ha })\end{array}$ \\
\hline Under 1 & $\begin{array}{c}1368 \\
(27 \%)\end{array}$ & $\begin{array}{c}703 \\
(4 \%)\end{array}$ & $\begin{array}{c}2389 \\
(36 \%)\end{array}$ & $\begin{array}{l}1184 \\
(6 \%)\end{array}$ & $\begin{array}{c}3596 \\
(43 \%)\end{array}$ & $\begin{array}{l}1689 \\
(8 \%)\end{array}$ \\
\hline $1-3$ & $\begin{array}{c}1877 \\
(37 \%)\end{array}$ & $\begin{array}{c}3421 \\
(18 \%)\end{array}$ & $\begin{array}{l}2391 \\
(36 \%)\end{array}$ & $\begin{array}{l}4238 \\
(21 \%)\end{array}$ & $\begin{array}{l}2885 \\
(35 \%)\end{array}$ & $\begin{array}{l}5059 \\
(23 \%)\end{array}$ \\
\hline $3-5$ & $\begin{array}{c}857 \\
(17 \%)\end{array}$ & $\begin{array}{l}3309 \\
(17 \%)\end{array}$ & $\begin{array}{c}891 \\
(14 \%)\end{array}$ & $\begin{array}{c}3443 \\
(17 \%)\end{array}$ & $\begin{array}{c}915 \\
(11 \%)\end{array}$ & $\begin{array}{l}3531 \\
(16 \%)\end{array}$ \\
\hline $5-10$ & $\begin{array}{c}623 \\
(12 \%)\end{array}$ & $\begin{array}{c}4134 \\
(22 \%)\end{array}$ & $\begin{array}{c}580 \\
(9 \%)\end{array}$ & $\begin{array}{c}3891 \\
(19 \%)\end{array}$ & $\begin{array}{c}562 \\
(7 \%)\end{array}$ & $\begin{array}{c}3794 \\
(18 \%)\end{array}$ \\
\hline $10-20$ & $\begin{array}{c}238 \\
(5 \%)\end{array}$ & $\begin{array}{l}3033 \\
(16 \%)\end{array}$ & $\begin{array}{c}261 \\
(4 \%)\end{array}$ & $\begin{array}{c}3324 \\
(16 \%)\end{array}$ & $\begin{array}{c}211 \\
(3 \%)\end{array}$ & $\begin{array}{l}2724 \\
(13 \%)\end{array}$ \\
\hline $20-60$ & $\begin{array}{c}92 \\
(2 \%)\end{array}$ & $\begin{array}{l}2614 \\
(14 \%)\end{array}$ & $\begin{array}{c}93 \\
(1 \%)\end{array}$ & $\begin{array}{l}2644 \\
(13 \%)\end{array}$ & $\begin{array}{c}79 \\
(1 \%)\end{array}$ & $\begin{array}{l}2246 \\
(11 \%)\end{array}$ \\
\hline Above 60 & $\begin{array}{c}15 \\
(0.3 \%)\end{array}$ & $\begin{array}{c}1935 \\
(10 \%) \\
\end{array}$ & $\begin{array}{c}14 \\
(0.2 \%)\end{array}$ & $\begin{array}{l}1683 \\
(8 \%) \\
\end{array}$ & $\begin{array}{c}13 \\
(0.2 \%)\end{array}$ & $\begin{array}{c}2368 \\
(11 \%) \\
\end{array}$ \\
\hline
\end{tabular}

Source: Agricultural Census Organization

\section{Employment Choice Making}

The modeling framework assumes a rural household member who chooses among farm and nonfarm employment. The employment choice model is based on some basic assumptions. The individual is not a subsistence farmer who solely relies on the farm for production as well as consumption. Rather, he can purchase labor and other inputs from the market and also sell its labor services and farm output in market. The choice of activity for income earning by the individual 
depends on the opportunity-set available and some policy variables that may affect his decision. The welfare is summarized in a utility function and the individual is essentially a utility maximizing agent. The model assumes a competitive labor market and hence we can take all prices as exogenous. This model is adopted from Huffman (1980) with some modifications where, household is simultaneously a consuming as well as producing unit.

We employed income-leisure approach to examine the labor supply and production decisions of the individual such as, individual preferences are defined over income and leisure. The utility function is assumed to be strictly quasiconcave, and the indifference curves are strictly convex. Labor supply decision of the individual can be viewed as utility maximizing subject to time, income and production constraints. The utility function comprises of a vector of leisure activities $(L)$, a vector of purchased goods $\left(Y_{1}\right)$, contingent on a vector of intangible exogenous factors $\left(Y_{2}\right)$ such as age, education and social capital and opportunity set $\left(Y_{3}\right)$ including tangible assets of the individual such as, land holding, livestock holding, vehicle ownership etc. The utility function is specified as follows.

$U=U\left(L, Y_{1} ; Y_{2}, Y_{3}\right)$ such as, $d U / d L>0$ and, $d U / d Y_{1}>0$

The individual faces time, budget and technology constraints. Total time endowment of the individual can be allocated between nonfarm $\left(X_{0}\right)$ and farm activities $\left(X_{l}\right)$, and leisure $(L)$.

$T=X_{0}+X_{1}+L$

The work choice of the individual is assumed to be conditional on earnings. Therefore, the budget constraint can be given as Equation (3).

$\left(P_{0} Q_{0}-W_{0} X_{4}\right)+(P Q-W X)+I=P_{1} Y_{1}$

Where $P_{0}$ and $Q_{0}$ represents respectively the price and output of nonfarm activity, while $P$ and $Q$ represent the price and output vectors of farm activity and $I$ represents transfer received. The input costs of the farm and nonfarm sectors are represented by $W X$ and $W_{0} X_{4}$ respectively. The nonfarm work may earn the individual either a wage or income earned being self-employed. To simplify the model, we specify the net gain from farm and nonfarm activities. Hence, Equation (3) represent the budget constraint showing that total expenditures equal to income earned through paid work in the farm and nonfarm sector, and transfers.

The farm output is produced using labor inputs $\left(X_{1}\right)$; a vector of purchased inputs $\left(X_{2}\right)$ such as seeds, fertilizer, and energy inputs; a vector of intangible inputs $\left(X_{3}\right)$ capturing the human capital and productive capacity such as education, 
training and skills; policy variables and infrastructural facilities (Inf). The inputs $\left(X_{3}\right)$ that affect the productive efficiency of worker include credit disbursement, road access, transport services that are exogenous. The production function of the farm output is given below.

$Q=f\left(X_{1}, X_{2} ; X_{3}\right.$, Inf $)$ where $d Q / d X_{1}>0, d Q / d X_{2}>0$ form.

Similarly, the production function in the nonfarm sector takes following

$Q_{0}=g\left(X_{0}, X_{4} ; X_{3}\right.$, Inf $)$ where $d Q / d X_{0}>0, d Q / d X_{4}>0$

The nonfarm output $Q_{0}$ depends on the labor services devoted to the nonfarm sector $\left(X_{0}\right)$ and a vector of purchased inputs $\left(X_{4}\right)$. The output in the nonfarm sector again depends on human capital $\left(X_{3}\right)$ and publically provided goods (Inf). The conditions for the optimum farm and nonfarm activities of the variable inputs in the utility function $\left(L, Y_{1}\right)$ and the variable inputs in farm output production function $\left(X_{1}\right.$ and $\left.X_{2}\right)$ are obtained by optimizing the utility function subject to the constraints given in Equations (2), (3), (4) and (5).

$\mathcal{L}\left(L, Y_{1}, X_{1}, X_{o}, Q, Q_{o}\right)=U\left(L, Y_{1}\right)+\lambda_{l}\left(T-X_{0}-X_{1}-L\right)+\lambda_{2}\left[\left(P_{o} . Q_{o}-W_{o} . X_{4}\right)+\right.$ (P. $\left.\left.Q-W . X)+I-P_{1} . Y_{1}\right)\right]+\lambda_{3}\left(Q-f\left(X_{1}, X_{2}\right)+\lambda_{4}\left(Q_{o}-g\left(X_{o}, X_{4}\right)\right.\right.$

Where $\lambda s$ represent Lagrange multipliers. The first order conditions by taking partial derivatives for an interior solution are given Equation (7) through (16). First order conditions are listed in the order in which variables are written in the Langrage function.

$$
\begin{aligned}
& \frac{\partial U(.)}{\partial L}-\lambda_{1}=0 \\
& \frac{\partial U(.)}{\partial Y_{1}}-\lambda_{2} P_{1}=0 \\
& -\lambda_{1}-\lambda_{3} \frac{\partial f(.)}{\partial X_{1}}=0 \\
& -\lambda_{1}-\lambda_{4} \frac{\partial g(.)}{\partial X_{0}}=0 \\
& \lambda_{2} P+\lambda_{3}=0 \\
& \lambda_{2} P_{0}+\lambda_{4}=0 \\
& T-X_{o}-X_{1}-L=0 \\
& \left(P_{0} \cdot Q_{0}-W_{0 .} X_{4}\right)+\left(P . Q-W_{2} \cdot X_{2}\right)+I-P_{1} . Y_{1}=0 \\
& Q-f\left(X_{1}, X_{2}\right)=0
\end{aligned}
$$


$Q_{o}-g\left(X_{o}, X_{4}\right)=0$

Equations (7) - (16) show that an individual's decision on the work-leisure choice and his choice of farm and nonfarm work depends on various factors including, human capital and skills for nonfarm work, infrastructure and some other factors. Equations (7), (9) and (10) give equilibrium time allocation conditions at farm work, leisure and nonfarm work respectively. The marginal conditions can be obtained by dividing; Equation (7) by (9) in Equation (17), (7) by (10) in Equation (18), and (9) by (10) in Equation (20).

$\frac{U_{L}}{f_{X 1}}=-\lambda_{3}$

It implies that marginal rate of substitution between leisure and farm work depends upon the marginal utility of leisure and the marginal productivity of that hour in the farm work. Similarly, the choice between leisure and nonfarm work can be given as follows.

$\frac{U_{L}}{g_{X 0}}=-\lambda_{4}$

This shows that comparison between leisure and nonfarm work choice depends on the marginal utility of an extra hour of leisure and the marginal productivity of that hour in the nonfarm work. Because $\lambda_{3}$ and $\lambda_{4}$ are marginal contributions in utility resulting from relaxing farm and nonfarm time which implies that at equilibrium $\lambda_{3}=\lambda_{4}$.

$\frac{U_{L}}{f_{X 1}}=\frac{U_{L}}{g_{X 0}}$

and

$\frac{f_{X 1}}{g_{X 0}}=\frac{\lambda_{4}}{\lambda_{3}}$

Because $\lambda_{3}=\lambda_{4}$ :

$\frac{f_{X 1}}{g_{X 0}}=1$

$f_{X 1}=g_{X 0}$

Thus, dynamically efficient time allocation of the individual in the farm and nonfarm activities must be such that marginal productivity across different activities would remain equal. This result is also shown intuitively in Equation (19). Using these marginal conditions along with Equations (8) and (13)-(16), we can get the optimal demand functions for $X_{1}, X_{\mathrm{o}}$ and $L$. By substituting Equations (14), (15) 
and (16) into (13), we get a single total resource constraint. In this framework, the demand for $X_{0}$ and $X_{1}$ are for the production purpose while leisure is demanded directly for consumptive purpose. The choice variables $L, X_{1}$ and $X_{0}$ can be shown as functions of several exogenous variables in the model as follows.

$X_{1}^{*}=f\left(Y_{2}, Y_{3}, P_{0}, I, X_{2}, X_{3}, I n f, W_{2}\right)$

$L^{*}=f\left(P_{0}, I, X_{3}, X_{4}, W_{0}\right)$

and,

$X_{0} *=T-f\left(P_{0}, I, X_{3}, X_{4}, W_{0}\right)-f\left(Y_{2} ., Y_{3}, P_{0}, I, X_{3}, X_{4}, I n f, W_{0}\right)$

$X_{0}^{*}=l\left(Y_{2} ., Y_{3}, P, P_{0}, I, X_{2}, X_{3}, I n f, W_{0}, W_{2}, T\right)$

The labor supply functions of rural workers in the farm and nonfarm sector are presented by Equation (23) and (25). Equation (24) gives the demand function for leisure. These functions show that the decision on the work-leisure choice and the choice of work in the farm or nonfarm sector can be explained by multiple factors including, individual characteristics and asset holdings, market conditions, and policy variables. The empirical model based on this theoretical framework and estimation result for individual choice in the rural sector of Pakistan is presented in the subsequent section.

\section{The Data and Empirical Model}

The empirical part of the study uses data obtained from two national surveys of Pakistan namely the PSLM 2010-11 and the PIHS 2001-02. Our approach is to separately estimate models for these two datasets. Tables 2 provide a comparison of the share of different sources in household income. It shows that percentage of 'self-employed' and 'unpaid family workers' has decreased whereas that of 'employees' has increased in PSLM 2010-11 as compared to PIHS 2001-02. Table 3 shows several secondary categories of nonfarm income and their shares including, (i) nonfarm rural wage employment, (ii) nonfarm rural self-employment, and, (iii) income earned as an employer. The table shows that nonfarm employment is rising especially due to nonfarm paid employees whereas, the share of livestock and food production remained rather static. PIHS 2001-02 covers around 16,314 households and provides information on socioeconomic status, savings, and income and consumption patterns of the workers of sampled households at the national as well as provincial levels with a rural-urban breakdown. ${ }^{3}$

3 We have dropped unpaid family workers doing farm work from the dataset, and hence, the individuals' data used in this analysis comprises of paid workers only. 
Table 2: Distribution of Rural Earners by Employment Status in Pakistan

\begin{tabular}{lcc}
\hline Employment Status & $\mathbf{2 0 0 1 - 0 2}$ & $\mathbf{2 0 1 0 - 1 1}$ \\
\hline Employer & 0.73 & 0.28 \\
Self employed & 29.06 & 27.60 \\
Unpaid family helper & 34.54 & 25.53 \\
Employee & 33.26 & 45.12 \\
Not active economically & 2.41 & 1.48 \\
\hline
\end{tabular}

Note: Above values are in percentages

Source: Federal Bureau of Statistics

Table 3: Distribution of Employment Choice in the PIHS 2001-02 and PSLM 2010-11

\begin{tabular}{lcccccc}
\hline & \multicolumn{3}{c}{ PIHS 2001-02 } & \multicolumn{3}{c}{ PSLM 2010-11 } \\
\cline { 2 - 7 } Employment Status & Non-Farm & Farm & Total & Non-Farm & Farm & Total \\
\hline Employer & 108 & 39 & 147 & 50 & 0 & 50 \\
Self employed & 1591 & 234 & 1825 & 1,526 & 3 & 1,529 \\
Paid employee & 5158 & 1961 & 7119 & 7,126 & 1,923 & 9,049 \\
Own cultivator & 0 & 2134 & 2134 & 0 & 1,756 & 1,756 \\
Sharecropper & 0 & 902 & 902 & 0 & 585 & 585 \\
Contract cultivator & 0 & 214 & 214 & 0 & 214 & 214 \\
Livestock & 0 & 413 & 413 & 0 & 534 & 534 \\
Total & 6857 & 5897 & 12754 & 8,702 & 5,015 & 13,717 \\
\hline
\end{tabular}

Source: Federal Bureau of Statistics

The analysis uses data from 12,750 individuals from 8,983 rural households. Similarly, the data set used in the analysis of PSLM 2010-11 comprises of 13,700 rural paid workers from the farm and nonfarm sectors. The choice of occupation of an individual may consist of a number of inter-related decisions. The foremost important question would be, whether an individual chooses to partake in a particular economic activity? If yes, then which activity will be undertaken? Various studies examined the relationship between employment choice and individual characteristics such as gender, education, road access, access to electricity and water, landholding (Adams and Alderman, 1992; Alderman et al., 1996; Arif et al., 2000; Huffman, 2001; Yúnez-Naude and Taylor, 2001; Berdegue' et al., 2001; Akbar and Jamil, 2012; Alvi and Jamil, 2018). Since various aspects of policy are expected to have different effects on work decisions, it essentially is an empirical question. Employment choice depends on various individual characteristics, household attributes and external regional factors and the dependent variable is dichotomous in the model with farm and nonfarm options, and we estimated a logit model as follows.

$\theta_{i}=\beta_{o}+\beta_{1}$ Gender $_{i}+\beta_{2}$ Edu $_{i}+\beta_{3}$ Age $e_{i}+\beta_{4 S_{-} \text {land }_{i}}+\beta_{5 m_{-}}$land $_{i}+\beta_{6} l_{-}$land $_{i}+$ $\beta 7 M k t \_$Access $+\beta_{8}$ Information $+\beta{ }_{9}$ Connect $+\beta_{10} N_{i}+u_{i}$ 
Here $\theta_{i}$ represents employment choice and farm activity is the base category. The data and variable description and data sources used to estimate the Equation (26) are given in Table 4. The size of landholding is found in the literature as the most significant variable in individual employment choice making in the rural setting. The choice of farm employment of an individual is expected to be positively related with the size of landholding. The market access variable is dichotomous and will take value 1 if an individual responds consecutive yes for two questions that are, have they been enjoying a satisfactory road access from rural area to a nearby market and if yes, have they access to a regular transport service, and zero otherwise. Market access will increase the likelihood of an individual choosing nonfarm employment although it may also benefit the farm sector by raising their profits.

Table 4: Data and variables Description

\begin{tabular}{|c|c|c|}
\hline Variables & Construction & Expected Outcome \\
\hline Mkt_Access & $\begin{array}{l}\text { Market access: } \\
\text { Satisfactory road and transport service } \\
\text { (Dichotomous Variable) }\end{array}$ & $\begin{array}{l}\text { Satisfactory market access is } \\
\text { expected to increase the nonfarm } \\
\text { employment }\end{array}$ \\
\hline $\begin{array}{l}\text { s_land (Small) } \\
\text { m_land (Medium) } \\
\text { l_land (Large) }\end{array}$ & $\begin{array}{ll}\text { Size of Landholding: } & \\
\text { NO/Marginal land } & \text { Small } \leq 5 \text { acres } \\
\text { Medium } \leq 15 \text { acres } & \text { Large }>15 \text { acres }\end{array}$ & $\begin{array}{l}\text { Increase in landholding is expected to } \\
\text { increase the farm employment }\end{array}$ \\
\hline Gender & $\begin{array}{l}\text { Male / Female } \\
\text { (Dichotomous Variable) }\end{array}$ & $\begin{array}{l}\text { Female will be more likely to be } \\
\text { employed in nonfarm sector }\end{array}$ \\
\hline Edu & $\begin{array}{l}\text { Education variable: } \\
\text { Years of Schooling (Continuous variable) }\end{array}$ & $\begin{array}{l}\text { Increase in years of schooling will } \\
\text { increase the nonfarm employment }\end{array}$ \\
\hline Connect & $\begin{array}{l}\text { Connectivity: } \\
\text { Having landline or mobile phone }\end{array}$ & $\begin{array}{l}\text { Individuals having connectivity are } \\
\text { expected to seek nonfarm } \\
\text { employment }\end{array}$ \\
\hline Information & $\begin{array}{l}\text { Access to radio, } \mathrm{TV} \text {, or internet (Dichotomous } \\
\text { Variable) }\end{array}$ & $\begin{array}{l}\text { Exposure to information about jobs } \\
\text { will most likely result in higher } \\
\text { demand for nonfarm employment }\end{array}$ \\
\hline Commercial & $\begin{array}{l}\text { Monetary value of the building in Pakistani } \\
\text { rupees (Continuous variables) }\end{array}$ & $\begin{array}{l}\text { Increase in the value of commercial } \\
\text { building will discourage the farm } \\
\text { activity }\end{array}$ \\
\hline
\end{tabular}

Intuitively, landholding may lead an individual to choose farm activity whereas, education as human capital will motivate nonfarm employment. Similarly, connectivity can benefit both the farm and nonfarm sectors, but increased connectivity may result in an individual choosing the nonfarm sector employment due to an increased earnings prospects in commercial services or manufacturing sectors. Further, the probability of choosing a nonfarm employment is expected to increase if value of commercial landholding of the individual increases. 


\section{Results and Discussion}

The analysis aims to illuminate the factors that determine the employment choice of an individual in the rural settings of Pakistan. The analysis comprises of both a descriptive and regression analyses. Table 5 gives descriptive analysis which shows the association of each explanatory variable with the dependent variable. The table presents a two-way analysis of the categorical dependent variable with each of the explanatory variable. It provides statistical relationship between dependent and each explanatory variable using a Chi Square $(\chi 2)$ test measuring the association between the column (dependent) and row (explanatory) variables in a two-way table. We test the null hypothesis for the $\chi^{2}$-test assuming that there is no association between the variables while the alternative hypothesis is that there does exist an association between the variables. However, the nature of this association remained elusive as we cannot ascertain through this test the direction of relationship. Any of the explanatory variables, where the $p$-value of $\chi^{2}$-test is less than 0.05 implies the existence of an association between that explanatory

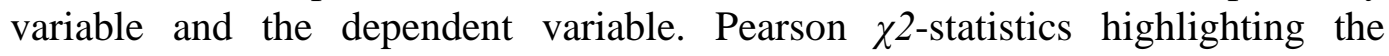
association between the variables is provided in Table 5 .

The age variable shows composition of different age groups in the labor force and indicates that $45 \%$ of nonfarm workers are young people whereas $35 \%$ of farm workers are old age people. A relatively low percentage of young people in farm activities indicates the employment shift from the farm to nonfarm sector of rural workers. The education variable also shows an obvious pattern. Households with members having higher education levels earn more from the nonfarm sector as compared to individuals having primary education. The relationship between landholding and employment choice is interesting. Small landholding increases the chances of households to assume farm operations. However, marginal and no landholding signify nonfarm employment of a household member. The pattern of the province variable indicates that farm activities dominate in the Punjab whereas, nonfarm employment is high in Balochistan province. Female workers' choice of employment tilts more towards the nonfarm sector.

The empirical estimation employs logit model for the individual's choice of employment using both qualitative and quantitative variables to identify different factors affecting choice among the farm and nonfarm activities. Table 6 presents separately the odd ratios of the logistic regression and the marginal effects of the logit model. A less than one value of odd-ratio suggests that the explanatory variable affects negatively the on-farm employment, and these results are further reiterated through marginal effects such that coefficients with negative sign show 
an inverse relation of the explanatory variable with the farm employment. The results show that only the age and landholding positively contribute to the farm activities. The age is positively and significantly affecting the farm employment that indicates more reliance on farm employment among the aged individuals. Pakistan is a relatively young population with one of the highest shares of youth in total population in the world. The country can get demographic dividend by converting human beings into human capital. It essentially will result the rural nonfarm sector to grow. All other variables including education, gender, market access, information, connectivity and commercial landholding are negatively related with the farm employment and earnings.

Table 5: Descriptive Analysis: measuring the Association with the Employment Choice using $\chi_{2}$

\begin{tabular}{|c|c|c|c|c|}
\hline \multirow[t]{2}{*}{ Age } & \multicolumn{2}{|c|}{ 2001-02 } & \multicolumn{2}{|c|}{$2010-11$} \\
\hline & Non-Farm & Farm & Non-Farm & Farm \\
\hline Young & $1859(29 \%)$ & $997(18 \%)$ & $3909(45 \%)$ & $1492(30 \%)$ \\
\hline Middle & $3491(54 \%)$ & $2705(48 \%)$ & $3546(41 \%)$ & $1970(39 \%)$ \\
\hline Old & $1157(18 \%)$ & $1963(35 \%)$ & $1247(14 \%)$ & $1553(31 \%)$ \\
\hline Total & 6507 & 5665 & 8702 & 5015 \\
\hline Pearson chi2(2) & \multicolumn{2}{|c|}{$\chi 2=512.301 ;$ Probability $=0.000$} & \multicolumn{2}{|c|}{$\chi 2=619.053 ;$ Probability $=0.00$} \\
\hline \multicolumn{5}{|l|}{ Education Level } \\
\hline Primary & $4058(62 \%)$ & $4714(83 \%)$ & $4916(56 \%)$ & $3982(79 \%)$ \\
\hline Middle & $866(13 \%)$ & $496(9 \%)$ & $2651(30 \%)$ & $847(17 \%)$ \\
\hline High & $1583(24 \%)$ & $455(8 \%)$ & $1135(13 \%)$ & $186(4 \%)$ \\
\hline Total & 6507 & 5665 & 8702 & 5015 \\
\hline Pearson chi2(2) & \multicolumn{2}{|c|}{$\chi 2=719.097 ;$ Prob.$=0.00$} & \multicolumn{2}{|c|}{$\chi 2=\mathbf{7 7 5 . 1 3 3 ;}$ Prob. $=\mathbf{0 . 0 0 0}$} \\
\hline \multicolumn{5}{|l|}{ Landholding } \\
\hline Marginal & $5483(84 \%)$ & $4660(82 \%)$ & $6716(77 \%)$ & $2855(57 \%)$ \\
\hline Small & $607(9 \%)$ & $579(10 \%)$ & $1532(18 \%)$ & $1449(29 \%)$ \\
\hline Medium & $295(5 \%)$ & $321(6 \%)$ & $303(3 \%)$ & $549(11 \%)$ \\
\hline Large & $122(2 \%)$ & $105(2 \%)$ & $151(2 \%)$ & $162(3 \%)$ \\
\hline Total & 6507 & 5665 & 8702 & 5015 \\
\hline Pearson chi2(3) & \multicolumn{2}{|c|}{$\chi 2=10.8706 ;$ Prob. $=0.012$} & \multicolumn{2}{|c|}{$\chi 2=\mathbf{7 1 0 . 3 6 1} ;$ Prob. $=\mathbf{0 . 0 0 0}$} \\
\hline \multicolumn{5}{|l|}{ Market Access } \\
\hline NO & $417(6 \%)$ & $218(4 \%)$ & $4407(51 \%)$ & $2066(41 \%)$ \\
\hline Yes & $6090(94 \%)$ & $5447(96 \%)$ & $4295(49 \%)$ & $2949(59 \%)$ \\
\hline Total & 6507 & 5665 & 8702 & 5015 \\
\hline Pearson chi2(1) & \multicolumn{2}{|c|}{$\chi 2=41.0503 ;$ Prob. $=0.000$} & \multicolumn{2}{|c|}{$\chi 2=\mathbf{1 1 3 . 9 3 6 8}$ Prob. $=\mathbf{0 . 0 0 0}$} \\
\hline \multicolumn{5}{|c|}{ Information Access } \\
\hline NO & $3635(56 \%)$ & $3896(69 \%)$ & $3892(45 \%)$ & $2918(58 \%)$ \\
\hline Yes & $2858(44 \%)$ & $1762(31 \%)$ & $4810(55 \%)$ & $2097(42 \%)$ \\
\hline Total & 6493 & 5658 & 8702 & 5015 \\
\hline Pearson chi2(1) & \multicolumn{2}{|c|}{$\chi 2=212.6731 ;$ Prob. $=0.000$} & \multicolumn{2}{|c|}{$\chi 2=\mathbf{2 3 0 . 5 7 3 1}$ Prob. $=\mathbf{0 . 0 0 0}$} \\
\hline \multicolumn{5}{|c|}{ Non-Agriculture Assets } \\
\hline NO & $6365(98 \%)$ & $5583(99 \%)$ & $8263(95 \%)$ & $4867(97 \%)$ \\
\hline Yes & $142(2 \%)$ & $82(1 \%)$ & $439(5 \%)$ & $148(3 \%)$ \\
\hline Total & 6507 & 5665 & 8702 & 5015 \\
\hline Pearson chi2(1) & \multicolumn{2}{|c|}{$\chi 2=12.0010 ;$ Prob. $=0.001$} & \multicolumn{2}{|c|}{$\chi 2=34.046 ;$ Prob. $=0.000$} \\
\hline
\end{tabular}

The marginal effects posit that education as proxied by years of schooling, has a negative relationship with the dependent variable. That is, nonfarm employment increases as education level of an individual increases. Fafchamps and 
Quisumbing (1999) also show that human capital development through education results in reallocation of labor from low productivity farm activities to nonfarm work that ultimately raises household incomes ${ }^{4}$. Batool and Jamil (2019) estimate determinants of nonfarm income and also finds that nonfarm employment of a worker in rural areas strongly depends on age, education, and distance to market etc. In rural areas of the developing countries, infrastructure is a critical constraint that limit the access to work for labor and sometimes, inadequate infrastructure raises the burden of unpaid family members who engage themselves merely in household chores such as cooking, collecting wood and potable water for domestic use instead of paid work.

The three categories of landholding dummy appear significant and positively affect farm activity with higher marginal effects. The base category in this case is no landholding. Higher landholding and wealth of the family reduces the likelihood that a family member seeks a nonfarm work. Wealth can arguably be a source of reducing risk through providing income without work that may further reduce the motivation for nonfarm paid work. The relationship of the value of commercial assets with farm employment is found negative. This can be explained on the basis of specialization such that individuals who own agricultural land tend to specialize in the farm sector whereas, commercial assets holding motivate the nonfarm sector. The market access and information are also significant in the model that favors nonfarm employment. Among rural households of Pakistan, the insufficient availability of information sources such as internet and computers and lack of skills and training limit the individuals' capacity to timely respond to the new market trends that ultimately decrease their wellbeing. The gender and connectivity variables become more favorable to the nonfarm choice in the 201011 as compared to 2001-02 whereas, connectivity was insignificant in the estimation of PIHS 2001-02.

The model is robust as the results are consistent with data from both the surveys. The analysis clearly shows that human capital holding drive the individuals to nonfarm employment while agricultural landholding lead to farm activity. The policy variables including market access, information, and connectivity exclusively favor the nonfarm employment with the proviso that workers are equipped with education and training. These results are consistent with the finding of Pakistan Rural Household Panel Survey (PRHPS). It further finds that the nonfarm sector is bigger than the farm sector in rural areas but nonfarm

\footnotetext{
${ }^{4}$ As most of the farmers are non-progressive hence, farm sector is generally considered a low productivity sector. This is especially true for subsistence farming but still in commercial farming, the productivity is low that is why, agricultural sector requires many subsidies and price support policies.
} 
enterprises are constrained by poor supply of electricity and lack of credit availability.

Table 6: Estimation Results of the Model for the PIHS 2001-02 and PSLM 2010-11

\begin{tabular}{lcccc}
\hline \multirow{2}{*}{ Farm Choice } & \multicolumn{2}{c}{$\mathbf{2 0 0 1 - 0 2}$} & \multicolumn{2}{c}{$\mathbf{2 0 1 0 - 1 1}$} \\
\hline Gender & Odds Ratio & dy/dx & Odds Ratio & dy/dx \\
Education & $1.02^{*}$ & 0.00 & $0.58^{*}$ & -0.14 \\
Age & $0.89^{*}$ & -0.00 & $0.89^{*}$ & -0.03 \\
Small Landholding & $1.41^{*}$ & 0.01 & $1.03^{*}$ & 0.01 \\
Medium Landholding & $1.28^{*}$ & 0.02 & $2.82^{*}$ & 0.30 \\
Large Landholding & $1.54^{*}$ & 0.02 & $7.03^{*}$ & 0.44 \\
Market Access & $1.63^{*}$ & 0.04 & $4.60^{*}$ & 0.35 \\
Information Source & - & - & $0.70^{*}$ & -0.08 \\
Connectivity & $0.68^{*}$ & -0.01 & $0.65^{*}$ & -0.10 \\
Commercial & 1.00 & 0.02 & $0.84^{*}$ & -0.04 \\
Constant & $0.70^{*}$ & -0.04 & $0.53^{*}$ & -0.13 \\
\hline
\end{tabular}

Note: * represents significance at $5 \%$ level.

\section{Conclusion}

The study first develops a theoretical model of individuals' work choice in the rural set-up in order to find appropriate policy interventions and institutional arrangements that may be required for sustainable income. Secondly, it estimates the individual employment choice model and show that tangible and intangible asset endowments of rural workers may affect this choice in Pakistan. Thirdly, it compares the results of estimated models involving the two dataset that are a decade apart. The theoretical model gives the worker's demand functions for leisure time and farm and nonfarm activities. The empirical model shows that ownership and size of agricultural land, and the worker's age contribute positively to farm employment while, human capital drive individuals to nonfarm sector. Likewise, nonfarm paid employment is an obvious first choice for female workers. Additionally, satisfactory access to road and transport, connectivity and access to information technology and formal credit services are found to be motivating the nonfarm activities. Over the past few decades, improved inputs and mechanization increases the labor productivity of farm workers. Having all other inputs fixed such as land and water, a rising productivity reduces labor demand in the farm operations and a lot of rural household workers become under-employed. This excess farm labor either remained poor for being unemployed or migrate to urban areas for jobs.

The comparison of two data sets show that rural nonfarm sector is gaining its share in the employment and income. The number of paid employees, own cultivators and sharecroppers in the farm category drops in PSLM-2010-11 as 
compared to PIHS-2001-02 whereas, a slight increase in witnessed in the livestock farmers. This is consistent with the theory that suggests a full employment and if a farm worker earns less than its opportunity return, a net transfer of labor from farm to the nonfarm sector must occur.

The study threw away the misconception that only farm employment can raise income and economic wellbeing among the rural poor and highlighted that the size of rural nonfarm sector is growing. The nonfarm sector has enormous potential in providing employment in rural areas that can ensure sustainable income for rural households. Overall, our results are fairly consistent with the earlier studies which show that landholding is the most important variable in the employment choice of an individual in rural setting. Rosegrant and Evenson (1992) find that the total factor productivity growth is highly contributing to total output growth and the main source of this productivity growth have been the research and extension services. Economics literature has recognized that improvement in human capital is key determinant of economic growth. As economy and human capital develops, the economic activities undergo a process of transformation and the composition of labor also tend to change.

Public provision of infrastructure in the form of road, transport and formal credit plays a role in employment choice and these findings suggest that focus of policy should be on education and training to provide an enabling environment for sustainable earnings of individuals. The vocational and entrepreneurial skills development may help small enterprises that serve to link the rural economy with the markets and ensure a sustainable income for the rural household. It will also help to overcome the sociocultural barriers that confine female members merely to unpaid family workers and impede their participation in paid economic activities. 


\section{References}

Adams, R. H., \& Alderman, H. (1992). Sources of income inequality in rural Pakistan: A decomposition analysis. Oxford Bulletin of Economics and Statistics, 54(4), 591-608.

Akbar, M., \& Jamil, F. (2012). Monetary and fiscal policies' effect on agricultural growth: GMM estimation and simulation analysis. Economic Modelling, 29(5), 1909-1920.

Alderman, H., Behrman, J. R., Ross, D. R., \& Sabot, R. (1996). Decomposing the gender gap in cognitive skills in a poor rural economy. Journal of Human Resources, 31(1), 229-254.

Alvi, S., \& Jamil, F. (2018). Impact of climate change and technology adoption on cereal yields in South Asian countries. European Journal of Sustainable Development, 7(3), 237-246.

Anwar, T., Qureshi, S. K., \& Ali, H. (2004). Landlessness and rural poverty in Pakistan. The Pakistan Development Review, 43(4), 855-874.

Arif, G. M., Nazli, H., \& Haq, R. (2000). Rural non-agriculture employment and poverty in Pakistan. The Pakistan Development Review, 39(4), 1089-1110.

Batool, S., \& Jamil, F. (2019). Rural employment and income diversification in Pakistan. Pakistan Journal of Agricultural Sciences, 56(2), 503-510.

Berdegué, J. A., Ramírez, E., Reardon, T., \& Escobar, G. (2001). Rural nonfarm employment and incomes in Chile. World Development, 29(3), 411-425.

Birner, R., \& Resnick, D. (2010). The political economy of policies for smallholder agriculture. World Development, 38(10), 1442-1452.

Chang, H. H., He, J., \& Saeliw, K. (2017). The role of off-farm labor participation decisions of married farm couples on farm direct marketing in Taiwan. The Developing Economies, 55(1), 3-22.

De Haan, L., \& Zoomers, A. (2005). Exploring the frontier of livelihoods research. Development and Change, 36(1), 27-47.

De Janvry, A., \& Sadoulet, E. (2001). Income strategies among rural households in Mexico: The role of off-farm activities. World Development, 29(3), 467480 .

Diao, X., Hazell, P., \& Thurlow, J. (2010). The role of agriculture in African development. World Development, 38(10), 1375-1383. 
Fafchamps, M., \& Quisumbing, A. R. (1999). Human capital, productivity, and labor allocation in rural Pakistan. Journal of Human Resources, 34(2), 369406.

Government of Pakistan. (2018). Economic Survey (2017-2018). Ministry of Finance: Islamabad.

Huffman, W. E. (1980). Farm and off-farm work decisions: The role of human capital. The Review of Economics and Statistics, 62(1), 14-23.

Huffman, W. E. (2001). Human capital: Education and agriculture. Handbook of Agricultural Economics, 1, 333-381.

Malik, S. (1996). Determinants of rural poverty in Pakistan: A micro study. The Pakistan Development Review, 35(2), 171-187.

Mishra, A. K., \& Goodwin, B. K. (1997). Farm income variability and the supply of off-farm labor. American Journal of Agricultural Economics, 79(3), 880887.

Rigg, J. (2006). Land, farming, livelihoods, and poverty: Rethinking the links in the rural South. World Development, 34(1), 180-202.

Rosegrant, M. W., \& Evenson, R. E. (1992). Agricultural productivity and sources of growth in South Asia.American Journal of Agricultural Economics, 74(3), 757-761.

Start, D. (2001). The rise and fall of the rural nonfarm economy: Poverty impacts and policy options. Development Policy Review, 19(4), 491-505.

Wiggins, S. (2000). Interpreting changes from the 1970s to the 1990s in African agriculture through village studies. World Development, 28(4), 631-662.

Yúnez-Naude, A., \& Taylor, J. E. (2001). The determinants of nonfarm activities and incomes of rural households in Mexico, with emphasis on education. World Development, 29(3), 561-572. 